\title{
Discussion Reform of Forestry Panorama Course Teaching
}

\author{
Xiaoli Wang a1 ${ }^{\text {a }}$ Zilin Cao ${ }^{\text {b2 }}$ \\ ${ }^{a}$ Faculty of Natural Resources Southwest Forestry University Kunming China \\ ${ }^{b}$ Faculty of environmental science and engineering Southwest Forestry University Kunming China
}

\begin{abstract}
The existing problems such as teaching materials, teaching methods and assessment links of the forestry panorama course teaching are pointed out and some solutions to the problems in thinking are put forward. In addition, the importance and curriculum of the forestry panorama as an entry and enlightenment course is emphasized. The main goal of this paper is to make positive exploration for further deepening reform of course teaching and cultivate high-level forestry talents, and it is hoped to improve course teaching.
\end{abstract}

Index Terms: Forestry panorama; Teaching materials; Teaching methods; Assessment methods; Teaching reform

(C) 2012 Published by MECS Publisher. Selection and/or peer review under responsibility of the International Conference on E-Business System and Education Technology

\section{Introduction}

The big decision of the Chinese government at the turn of the century is the strategy for western development to accelerate the Midwest development. The protection and construction of ecology and environment has become a breakthrough point of the great development of the west with the natural forest protection engineering and converting cultivated land into forest/grass engineering thorough development. Forestry as the subject of ecological environment construction was endowed with great historic mission. Forestry high-tech talent is the most important resources for the great development of the west and increasing integrated competition ability of the western region. In recent years, much discussion of education teaching gradually in-depth whether to forestry from undergraduate course, master of different training level, or from the school-running features, curriculum setting, training objectives and so on the different angle has been done. Among these discussions for teaching courses spread around the forest cultivation course widely but work around forestry panorama course is very few[1-2]. Therefore, this paper is to explore a teaching way to meet the developing social demand as the course orientation of forestry college non-forestry major students to learn the forestry the main course and forestry "starter" course.

The orientation of forestry panorama is a discipline basic course and it is always as a forestry enlightenment course for non-forestry major students in the forestry colleges. The course is opened in grade two or three. The teaching purpose is to make students of the forestry college the non-forestry professional can grasp the future

\footnotetext{
The forest cultivation learning of yunnan provincial key construction

discipline aid (500018)

* Corresponding author.

E-mail address: ${ }^{1}$ Fjxlwang@yahoo.com.cn, ${ }^{2} \mathrm{Czl} @$ swfu.edu.cn
} 
study direction and lay the foundation for related major area of study. So it can be declared that forestry panorama is a general overview of professional study for undergraduates. Therefore, forestry panorama course teaching reform is an urgent and important task under the new situation, as the overall reform idea is shown in Fig.1.

\section{2. status and existing problems in Forestry panorama course}

\section{A. Attention is insufficient to this course}

As a discipline basic course, the effect of forestry panorama is self-evident. But there is little thought has been given about relation about this course and the other professional courses and the effect what its orientation will give students. What mentioned above has not get corresponding attention and consideration. Therefore, there is not enough attention has been paid to this course in the school and teachers. They think that the overview of course is not sexual backbone course and the course is always as elective course for students.

The purpose of students' learning this course is not clear.

It is a common phenomenon that students don't pay attention to this course in the learning. Many students regard it as merely a professional study start and just want to have slightly understanding of this course. They don't realize the importance of this course and don't study it hard. In fact, this course has a deeper level of teaching requirements and higher standard of teaching goal.

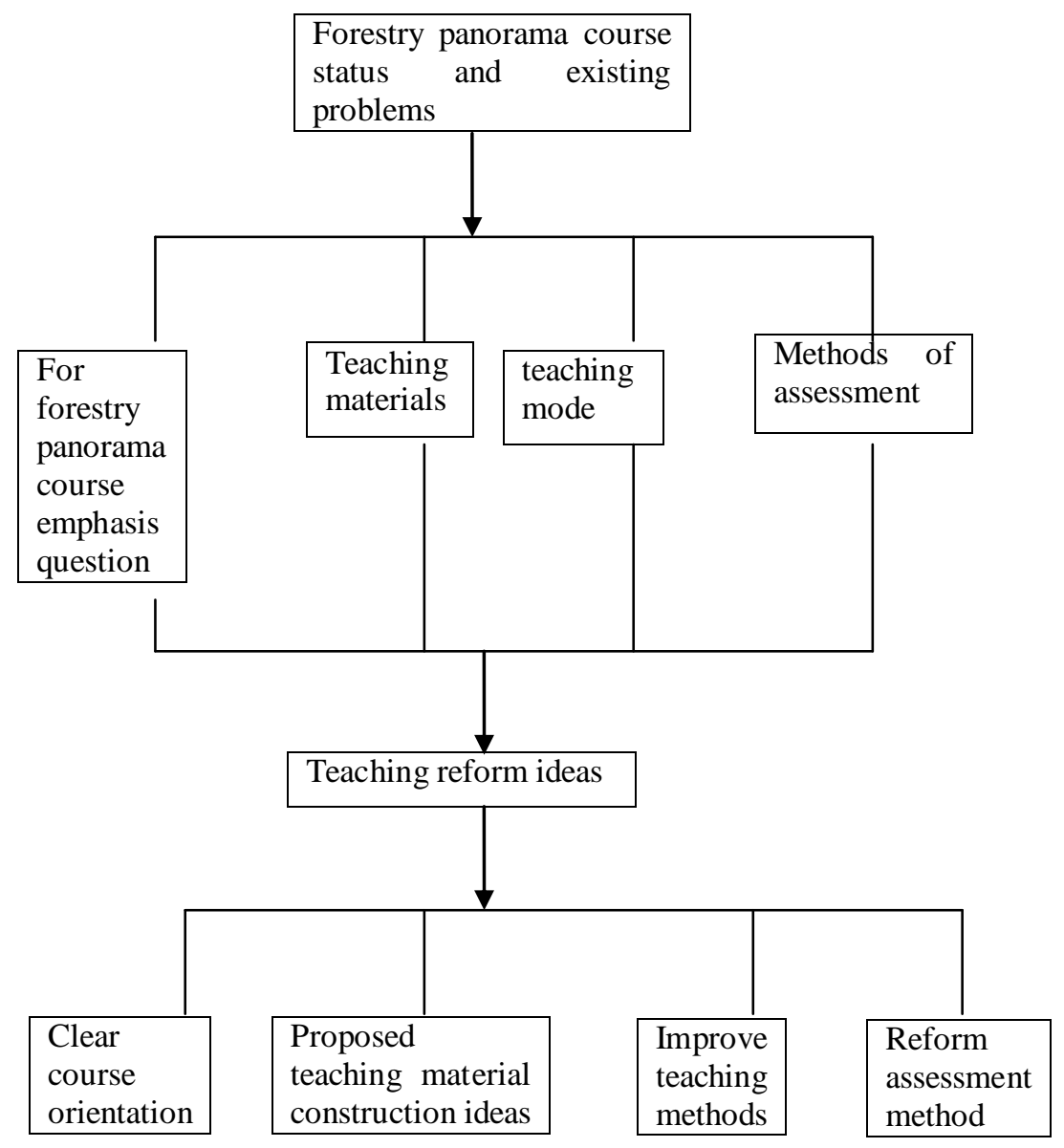


Fig. 1 Forestry Panorama course teaching reform

\section{B. Teaching materials}

At present, though forestry panorama has unified writing teaching material, the difference of our country climate conditions and soil conditions are very big and the tree species is very rich. It leads that forestry and forestry science has strong regional features. In addition teaching hours is limited, forestry panorama teaching contents are different records and loyalties in the national forestry universities and even the same university different teachers. Teaching material construction in the teaching process has a pivotal role because it is the carrier of teaching content and it bridges between teacher and student in the side of knowledge communication. Moreover, it is a starting point for students to expand more widely subject field by self-study. The unified writing teaching material of forestry panorama for current using made a significant contribution to cultivate forestry talents. But the main problem is that updating of unified writing teaching material is slow, at present textbooks have quite partial out-of-date contents, it cannot reflect the related disciplines of dynamic, which increases the teachers' teaching preparation work load, the result is that it affects the quality of teaching if instructor is reluctant to spend more energy to access information to supplement the teaching content and use scripted way of teaching. Hence, teaching material construction in forestry panorama course construction should be given more attention.

\section{Teaching methods}

In the current teaching mode, lecture in the class is the primary teaching method, there are lack of class discussions, group discussion and two-way multi-exchange. The theoretical teaching gets too large proportion in the class because experiment practice funds are shortage. The proportion of forestry panorama course that is with only theoretical teaching and without practice teaching in our university is above $70 \%$. Thus, teachers have much difficultly in the class and the teaching effect is bad. Moreover, teachers are difficult to truly understand the students' learning effects and acquire opinions in teaching method. The learning enthusiasm of students is not high and the participation of students is very few. The result is that it weakens the ability training and quality improvement to students.

\section{Assessment methods}

Test (assessment) is a kind of form to check the teaching effect that not only a check for studying effects of students but also a test for teaching level and teaching effect of teachers. At present, the forestry panorama inspection usually adopts comparative economics test that examination content involve the discipline of nouns concepts, terminology, basic theory and methods. The enthusiasm of students' study and self-esteem are damaged by this assessment way. The creativity and the development of personality of students are obstructed. Students pay attention to lecture notes, theoretical knowledge, memory ability and contempt practice operation, ability training, innovation. This common phenomenon has caused students to passive learning situation. The result is that the students testing scores is outstanding but they are unable to solve practical problems.

\section{3. thinking about reform of Forestry panorama course teaching}

A. The course orientation needs to be clear for formulating rational teaching plan and outline. The leading of the enlightenment course should be Strengthened; the blind of professional study should be reduced.

At present forestry panorama is elective courses in many professionals. It is suggested that this course should be converted from an elective course to a compulsory course. By way of making a reasonable teaching syllabus, this course can play a significant role as a introduction course.

A correct and successful orientation will have far-reaching influence for students four years of professional study since it is the introduction and enlightenment course. It is found that the non-forestry professional 
freshmen of our university don't deeply understand forestry by investigation, which is shown in table1.

TABLE 1 THE NON-FORESTRY PROFESSIONAL FRESHMEN TO FORESTRY UNDERSTANDING

\begin{tabular}{cl}
\hline Students proportion & \multicolumn{1}{c}{ The understanding of forestry } \\
\hline $30 \%$ & Forestry college backbone course(But it is a very paste concept) \\
$30 \%$ & Plant trees, with green relevant professional courses \\
$27 \%$ & Don't understand \\
$11 \%$ & $\begin{array}{l}\text { Forestry specialized subject liters undergraduate students, has certain forestry } \\
\text { professional basis }\end{array}$ \\
& Like forestry \\
\hline
\end{tabular}

The introduction of forestry basic concepts, characteristics, types and functions is essential in forestry panorama. As an old discipline, forestry has much discipline and comprehensive. Forestry contains extensive theory and technology content, such as forest botany, forest ecology, trees breeding, forest protection, forest cultivation, measuring the timber tree learn, forest management. However, such a vast subject system let freshmen confused. Therefore it is necessary to add content that the whole course system settings introduction. It can let students understand relationships with each other of each part teaching contents and let freshmen grasp a clear learning context. It is very important that confidence in study is established and good habits of study are cultivated for students.

\section{B. Teaching material construction}

The content of forestry panorama teaching material can be divided into two major parts. One kind is the core content that contains mainly knowledge of this subject; it constitutes the core knowledge system of the teaching material. The core content has characteristics of theoretical mature, more stable and strong commonality. The other kind is the dynamic strong content that has obvious technical, practicality, regional and disciplinary frontiers. Based on the characteristics of the teaching materials, this course teaching material construction can be used in two ways: the core content can be written by the national unified and the dynamic strong content can be written by the colleges or universities self-designed. Because the core content is relatively stable and it can be updates by five years or so and the dynamic strong content can be updated by one year of two years. The two kinds of teaching material of unified write and self-designed cooperate to use to mutually complementary.

\section{The teaching methods is improved by guiding the student to adopt research-oriented learning ways in appropriate link}

Usually, teacher talk is the main teaching form that is adopted by outlines course. Although there are now intuitive, vivid and illustrated the multimedia teaching, the active participation of students and the interaction between the teachers and students are insufficiency. It is suggested that the teaching methods can appropriately adopt research-oriented learning mode. The research-oriented learning mode is that students are active to carry on investigative study with the carrier of the subject research or project design with the help of teachers based on independent choice of students. The research-oriented learning mode does not emphasize some specific knowledge that learners have mastered while it attach importance to learning process and the ability of selection, judgment, interpretation and comprehensive [3]. Teachers can give a topic according to this curriculum 
knowledge setup to design. Students can collect data after class according to the topic. The class teaching can adopt a lecture, discussions, debates and other forms to encourage students passively studying to actively learning, stimulate students interest in learning and active classroom atmosphere.

\section{Assessment methods reform}

The scientific and reasonable assessment methods have positive promoting role to teaching. Our approach is: (1) The examination forms and methods are increased. The flexible test method and testing form were determined with the characteristics of course. We pay attention to student's ability assessment. The flexible test method and testing form include comparative economics, class discussions, curriculum design, course book report and teaching practice and others. (2) The examination content is flexible diversification. The examination content includes large amount of topic and includes question and answer or multiple-choice patterns, moreover, it covers frontier content of the subject, scientific BBS and hot disciplines etc. The examination category can check student's memory ability, lenovo ability, analytical ability, creative ability and comments ability etc [4-8]. It can make students pay attention to collect data, disciplinary development, positive thinking problem and achieve the purpose of promoting learning by way of testing.

\section{4. conclusion}

In all, as a main course for non-forestry major students in forestry colleges, forestry panorama can not give student specific knowledge like other main professional courses. However, author thinks that as an enlightenment course it should be given more attention in the circumstance that there are still many disputes in current professional education. We shall make it an important and "first class" course for student contacting forestry in combination with the development of the subject and effective guide. Moreover, it is hoped the viewpoints of this paper can cause colleague's thinking, and it can have positive boost for teaching reform of this subject.

\section{References}

[1] Zhang Jian, Gong Yuanbo, Chen Liqing. Facing the 21st century the forest cultivation curriculum reform thinking[J]. Journal of sichuan agricultural university,2000,18(supplement)75-76(in Chinese).

[2] Shen Guofang. Learn about the forest cultivation of textbook construction some historical review[J]. Journal of Beijing forestry university, 2002, 24(516): 280-283(in Chinese).

[3] Wu Lieyan. Moving towards Research Courses_-Taking basic design teaching for example[J]. Journal of Nanjing arts institute(fine arts and design). 2004(2): 5-9(in Chinese).

[4] Yang Zhenhua. Higher education concerning forestry talent training mode reform[J]. China's forestry education. 2000(3):36-39(in Chinese).

[5] Chen Ke,Xie Zhijun. With China's accession to the building-up of higher education development of forestry[J]. China's forestry, 2003(5):28-29(in Chinese).

[6] Hao Qingyu,Zhou Yuping. Talk about ordinary forestry college of improving the quality of teaching countermeasures[J]. China agricultural education, 2004(2): 9-21(in Chinese).

[7] Wang Shimin. secondary specialized school forest cultivation course teaching reform[J]. Journal of simao teachers'college,2008(6):97-99(in Chinese)

[8] Zhao Yan. A discussion on the improvement of teaching for the course "Introduction to Landscape Architecture" [J].Journal of architeciural education in nstitutdns of higher leraing,2008(4):105-107(in Chinese). 